\title{
OCCUPATIONAL STRESS, ORGANISATIONAL COMMITMENT AND ILL-HEALTH OF EMPLOYEES AT A HIGHER EDUCATION INSTITUTION IN SOUTH AFRICA
}

\author{
SE COETZEE \\ S ROTHMANN \\ WorkWell: Research Unit for People, Policy and Performance, \\ Potchefstroom Campus, North-West University
}

\begin{abstract}
The objectives of this study were to assess the indicators and moderators of occupational stress at a higher education institution in South Africa, as well as differences based on language and years of experience at the institution. A cross-sectional survey design was used. The participants included academic and support staff at a higher education institution $(N=372)$. An Organisational Stress Screening Tool (ASSET) and a biographical questionnaire were administered. Workload, control, work relationships and pay and benefits were the major occupational stressors in the institution. Compared to the international norm, participants reported higher levels of physical and psychological ill-health and perceived lack of commitment from the organisation. Analysis of variance revealed differences in occupational stress levels for all the biographical variables tested. Organisational commitment moderated the effect of occupational stress on ill-health.
\end{abstract}

\section{OPSOMMING}

Die doelstellings van hierdie studie was om die aanwysers en verligtende faktore van beroepstres in 'n hoëronderwysinstansie in Suid-Afrika te identifiseer, asook moontlike verskille gebaseer op taal en jare ervaring by die instansie te bepaal. 'n Dwarsdeursnee-opnameontwerp is gebruik. Die deelnemers het bestaan uit akademiese en ondersteuningspersoneel verbonde aan 'n hoëronderwysinstansie $(N=372)$. 'n Organisasiestresgraderingsinstrument (ASSET) en 'n biografiese vraelys is afgeneem. Oorlading, kontrole, werksverhoudinge en salaris en byvoordele was die vernaamste stressore in die instelling. Vergeleke met die internasionale norm, het deelnemers hoër vlakke van fisieke en psigologiese ongesondheid gerapporteer, en ook 'n gebrek aan verbondenheid komende van die werkgewer ervaar. Variansieanalise het verskille in werkstresvlakke uitgewys vir al die biografiese veranderlikes wat getoets is. Organisasieverbondenheid het die effek van beroepstres op ongesondheid gematig.

\begin{abstract}
Historically, working in a higher education institution has been considered relatively stress-free and highly satisfying (Willie \& Stecklein, 1982). In addition, Watts et al. (1991) found that $75 \%$ of university workers who reported long working hours, work overload and lack of support were nevertheless satisfied with their jobs. Doyle and Hind (1998) also found that $40 \%$ of female university lecturers in their sample who reported long working hours, still found their jobs intrinsically motivating, enjoyable and potentially rewarding. A possible explanation for this might be differences in work context factors, e.g. higher levels of autonomy, clarity and tenure and a 'collegiate culture', which emphasises consensual decision-making and shared values (French, Caplan \& Van Harrison, 1982) and working conditions.
\end{abstract}

Recently the world has started to change, and so must higher education institutions if they are to survive (Gilbert, 2000). In 1996, the results of an international survey of academic professions which was carried out using data from 14 countries reported that significant changes had taken place in higher education (Altbach, 1996). For example, academics now face demands for greater accountability, value for money, efficiency and quality, and an increase in remote and autocratic management styles. Studies among staff at higher education institutions in the United Kingdom showed the most significant stressors as new management styles, unmanageable workload, too much administrative paperwork, lack of information, change in conditions of service, lack of administrative support (Earley, 1994), inadequate resources, uncaring organisation, inadequate salary (Daniels \& Guppy, 1994), lack of opportunities for promotion, ineffective organisational communication and a rushed pace of work (Jackson \& Hayday, 1997; Kinman, 1996).

Requests for copies should be addressed to: S Rothmann, Department of Industrial Psychology, North-West University (Potchefstroom Campus), Private Bag X6001, Potchefstroom, 2520
These challenges, added to the increasing work load caused by massification of student numbers (Gilbert, 2000 ), life-long learning and adult learning (Shortlidge, 2003), changes in the market place (Blackmore, 2001; Rowley, 2000) and globalisation (Brown, 1999), will certainly have an impact on the well-being of employees at higher education institutions. Combined with a gradual erosion of pay and job security, these stressors are now being reflected in lower levels of job satisfaction and commitment (Kinman \& Jones, 2003).

Seldin (1991) found that the levels of stress of lecturers, administrators as well as support personnel, including paraprofessionals, secretaries and custodial staff who contribute to the daily operations and success of a higher education institution have increased in recent years and are likely to get worse. This is relevant for Gorschkov (1998) accentuated that stable and productive support systems in terms of higher education and training are of vital importance to any country in order to ensure sustainable economic, social and political reconstruction and development.

Psychological stress now appears to be a feature of occupational life for university staff, occurring not only in increasing levels in the United Kingdom (Kinman \& Jones, 2003), but also in Australia and New Zealand (Boyd \& Wylie, 1994; Gillespie, Walsh, Winefield, Dua \& Stough, 2001). Winefield et al. (in press) in their longitudinal study of occupational stress in Australian universities, found that $43 \%$ of academic staff, compared to $37 \%$ of general staff, were classified as possible 'cases' of psychological illness using the General Health Questionnaire (GH-12, Goldberg \& Williams, 1988). This compared to a $12 \%$ case rate in the Australian population overall. Kinman (2001) also reported a 53\% 'case' rate among academic staff at a university in the UK.

In South Africa the landscape of higher education is also changing. Since 1994, the post-apartheid government of South 
Africa has been aiming to redress effects of the apartheid era and move toward a democratic society. One of the focus areas of redress is the education system (Cross, Mungadi \& Rouhani, 2002). This has resulted in a restructuring of the broad higher education system, which implies consequences for the governance of all higher education institutions (Dlamini, 1995; Hugo, 1998). At the same time, the realities of globalisation require of higher education institutions to become internationally competitive (Du Toit, 2000).

The objectives of this study were to identify the occupational stressors for staff members in a higher education institution; to assess the relationship between occupational stress, organisational commitment and ill-health, and to analyse the differences between groups based on language and years of experience.

\section{Occupational stress, commitment and ill-health}

According to Cartwright and Cooper (2002), the literature presents many conflicting definitions of stress. These can be categorised into three types, namely stimulus, response and interactive definitions (Cooper, Dewe \& O'Driscoll, 2001). Stimulus based definitions view stress as a situational or environmental based stimulus, which impinges upon the person. Response based definitions define stress as an individual's psychological or physiological response to environmental/situational forces. The interactive type definitions, which are generally preferred defines stress as both the stimulus (source of stress or stressor) and the response (outcome or manifestation of stress or strain). Therefore Siu (2002) argued that a stressful transaction occurs when persons both exert an impact on and respond to their environment. Following a transactional perspective, stress arises when the demands of a particular encounter (as appraised by the individual) is about to exceed the resources available, thereby threatening the well-being (Lazarus, 1991) and bringing about change in the person's psychological and/or physiological condition in order to cope with the encounter (Cooper et al. 2001; Siu, 2002).

Lazarus and Folkman (1984) developed the notion of appraisal or perception, as a stressor - strain mediator. They suggest that the individual appraises the stressor (primary appraisal) and appraises their own ability to cope with it (secondary appraisal). Only when both appraisals are negative, when the stressor is perceived to be harmful and the individual feels that they do not have the resources to cope with it, will they suffer stress (Lazarus, 1991). In other words, a stressor has to be perceived and recognised by the individual as overwhelming their ability to cope, to be felt. Therefore, stress arise when individuals perceive that demands made upon them exceed their ability to cope (Cartwright \& Cooper, 2002).

A recent epidemiological survey conducted in the United Kingdom (Jones \& Hodgson, 1998) concluded that stress was the second most frequently reported condition of individuals who disclosed a work-related illness. It is evident, however, that in order for any organisation to address stress-related issues and implement effective interventions, it is necessary to diagnose the job characteristics and working conditions that the workforce perceive to be stressful, investigate the outcomes of any stressors that are experienced and establish whether any particular sub-group of the working population is at greater risk (Kinman, 2001).

Studies have shown that occupational stressors may result in mental, physical and behavioural stress reactions, such as burnout, depression and psychosomatic diseases (Houkes, Janssen, de Jonge \& Nijhuis, 2001). The link between unmanaged stress and the negative impact on health and wellbeing are well-demonstrated in stress research and are linked to severe physical consequences, some of which may be fatal (Winefield, Gillispie, Stough, Dua \& Hapuararchchi, 2002).
According to Siu (2002) and Winefield et al. (2002) there is significant evidence to suggest that chronic and high levels of occupational stress, left unchecked, is related to mental and physical well-being, job dissatisfaction, absenteeism, stressrelated injuries turnover and intention to quit. They have shown significant correlations between higher levels of psychological strain and incidences of self-reported stress-related health symptoms, such as sleeping difficulties, headaches, colds and other viral infections. Furthermore these symptoms are significantly associated with stress-related medical conditions reported by staff members, such as migraines, hypertension and coronary heart disease.

Recently, organisational commitment has been identified as a significant moderator of stress (Siu, 2002). Organisational commitment was not only related to most of the physical and psychological outcomes among workers, but also to the moderating effects on the stressor-health relationship. Organisational commitment therefore interacts with sources of stress at work to determine its outcomes. Siu (2002) argues that this indirect or moderating effect of commitment protects individuals from the negative effect of stress, due to the fact that it enables them to see direction in and attach meaning to their work. Organisational commitment can also provide people with stability and a feeling of belonging.

Cartwright and Cooper (2002) developed a model which includes occupational stressors, strain (ill-health) and organisational commitment (See Figure 1).

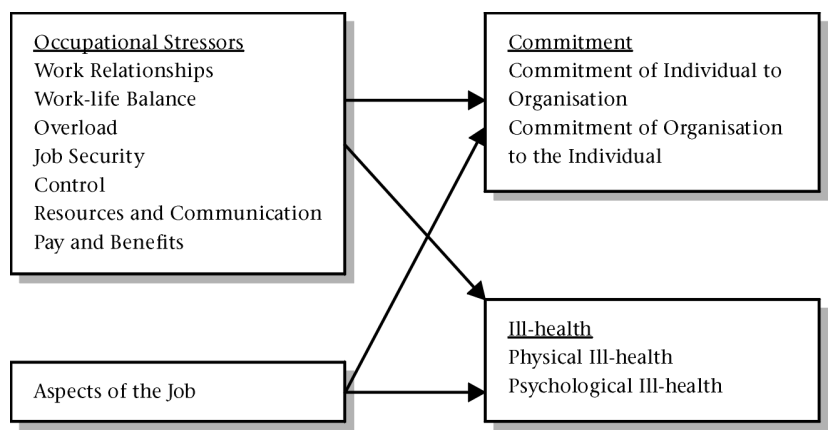

Figure 1: Model of occupational stress, commitment and ill-health

As can be seen in Figure 1, seven occupational stressors are distinguished, namely work relationships (i.e., poor or unsupportive relationships with colleagues and/or superiors, isolation and unfair treatment), work-life imbalance (i.e., when work interferes with the personal and home life of individuals), overload (i.e., unmanageable work loads and time pressures), job security (i.e., fear of job loss or obsolescence), control (i.e., lack of influence in the way work is organised and performed), resources and communication (i.e., having the appropriate training, equipment and resources), pay and benefits (i.e., the financial rewards that work brings) aspects of the job (i.e., sources of stress related to the fundamental nature of the job itself), are sources of stress. Commitment (including the individual's commitment to the organisation and the organisation's commitment to the individual) refers to an effect of stress. Poor health is an outcome of stress, which can be used to ascertain if workplace pressures have positive and motivating or negative and damaging effects. However, poor health may not necessarily be indicative of workplace stress. Individuals may, for example, be unwell because they choose not to lead a healthy lifestyle or may be unaware of how to do so (Cartwright \& Cooper, 2002).

In a study done by Tytherleigh (2002) on occupational stress in 14 higher education institutions in the UK, she tested work relations, work-life balance, overload, job security, control, 
resources and communication, job overall, pay and benefits as potential sources of stress. It was discovered that work relationships, job security, and resources and communication caused the highest levels of strain. However, despite the gradual erosion of job factors that once appeared to 'buffer' academics, high levels of job satisfaction remain (Tytherleigh, Webb, Cooper \& Ricketts, 2003). It was found that, whilst commitment levels were lower and levels of occupational stress were significantly higher in relation to work relationships, control and resources and communication compared to other occupational groups, higher education institution staff (non-academic as well as academic staff) reported statistically significantly lower levels of stress in relation to work-life balance, overload and job overall. They also reported statistically significantly lower levels of physical ill-health outcomes of stress and normative levels of psychological outcomes. Similar high levels of satisfaction with certain aspects of their work, together with high levels of perceived stressors and strains, were also identified by Doyle and Hind (1998) in their study of psychology lecturers. More recently, Kinman and Jones (2003) also found that several respondents thrived on the fact that their jobs were stressful.

\section{METHOD}

\section{Research design}

A cross-sectional survey design was used to achieve the study objectives (Shaughnessy \& Zechmeister, 1997). The measuring instrument used in this study (An Organisational Stress Screening Tool - ASSET) is most often used within a cross-sectional design. It is practically useful for organisations and not scientifically problematic (Cartwright \& Cooper, 2002).

\section{Participants}

The participants included academic and support staff at a higher education institution in South Africa. A total of 820 questionnaires were sent out: academic staff $(N=320)$; support staff $(N=500)$. A total of 372 completed questionnaires were received back. This comprised 175 academic and 197 support staff members. This gives a total response rate of $45,36 \%$ $(47,04 \%$ for academic staff and $52,96 \%$ for support staff). Females constituted 63\% of the participants. Different language groups were included in the study. A total of $55 \%$ of the participants were Afrikaans-speaking; 19\% English-speaking; $11 \%$ Setswana-speaking; and $15 \%$ spoke other indigenous languages. The majority (44\%) of the participants were married. In total, $25 \%$ of the population had obtained a Master's (or related) and/or a higher qualification.

\section{Measuring instrument}

An Organisational Stress Screening Tool (ASSET) was used in this study. The ASSET was developed by Cartwright and Cooper (2002) as an initial screening tool to help organisations assess the risk of occupational stress in their workforce. It measures potential exposure to stress in respect to a range of common workplace stressors. It also provides important information on current levels of physical health, psychological well-being and organisational commitment and provides data to which the organisation can be compared. The ASSET is divided into four questionnaires. The first questionnaire (37 items) measures the individual's perception of his or her job. The second questionnaire ( 9 items) measures the individual's attitude toward his or her organisation. The third questionnaire (19 items) focuses on the individual's health. The fourth questionnaire (24 items) focuses on supplementary information and includes questions on biographical information. These items are customised specifically for higher education institutions. The first three questionnaires of the ASSET is scored on a six-point scale with 1 (strongly disagree) to 6 (strongly agree). The fourth questionnaire is scored on a four-point scale with 1 (never) to 4 (often).

The ASSET has an established set of norms from a database of responses from 20000 workers in public- and private-sector organisations in the United Kingdom. The ASSET presents scores in sten (standardised ten) format. A sten is a standardised score based on a scale of 1 to 10 , with a mean of 5,5 and a standard deviation of 2 . The sten system enables meaningful comparison to the norm group. Most people (68\%) score between sten 3 and sten 8 . Scores that fall further from the mean (either in the high or the low direction) are considered more extreme. About 16\% score at the low end, and another $16 \%$ score at the high end.

Validity is still to be completed (Cartwright \& Cooper, 2002). Reliability is based on the Guttman split-half coefficient. All but two factors returned coefficients in excess of 0,70 ranging from 0,60 to 0,91 (Cartwright \& Cooper, 2002). Johnson and Cooper (2003) found that the Psychological Well-Being subscale has good convergent validity, with an existing measure of psychiatric disorders, the General Health Questionnaire (GHQ - 12; Goldberg \& Williams, 1988). Tytherleigh (2003) used the ASSET as an outcome measure of job satisfaction in a nationwide study of occupational stress levels in 14 English higher education institutions. A series of Cronbach alphas was carried out on each of the questions for the five ASSET subscales to identify the reliability of the ASSET questionnaire with these data. The values ranged from 0,64 to 0,94 , showing good reliability.

\section{Statistical analysis}

Descriptive statistics (means, standard deviations, skewness and kurtosis) were computed to analyse the data. Cronbach alpha coefficients were used to determine the internal consistency of the ASSET scales (Clark \& Watson, 1995). Pearson product-moment correlation coefficients were used to specify the relationship between the variables. In terms of statistical significance, it was decided to set the value at a $95 \%$ confidence interval level $(p=0,05)$. Effect sizes (Steyn, 1999) were used to decide on the practical significance of the findings. A cut-off point of 0,30 (medium effect, Cohen, 1988) was set for the practical significance of correlation coefficients. One-way analysis of variance (ANOVA) was used to determine the differences between the subgroups of the sample. Tukey's Standardised Range tests were used to determine the statistical significance of differences obtained during ANOVAs. According to Cohen (1988), $0,10=d=0,50$ indicates a small effect; $0,50=d=0,80$ indicates a medium effect and $d=0,80$ indicates a large effect. In terms of the current research, a cut-off point of 0,50 (medium effect) was set for the practical significance of the differences between group means.

Structural equation modelling (SEM) methods as implemented by AMOS (Arbuckle, 1997) were used to test a model of occupational stress. The following goodness-of-fit indices were used to summarise the degree of correspondence between the implied and observed covariance matrices (Byrne, 2001): (1) The $\chi^{2}$; (2) The $\chi^{2} /$ degrees of freedom ratio (CMIN/DF); (3) The Goodness of Fit Index (GFI); (4) The Adjusted Goodness-of-Fit Index (AGFI); (5) The Normed Fit Index (NFI); (6) The Comparative Fit Index (CFI); (7) The Tucker-Lewis Index (TLI), and (8) The Root Mean Square Error of Approximation (RMSEA).

\section{RESULTS}

The descriptive statistics of the ASSET dimensions and items are reported in Table 1 . The sten scores reflect the mean scores of the participants compared to international norms $(N=20000)$. 
TABLE 1

DesCriptive STATISTICS AND AlPHa COEFFicients OF THE ASSET

\begin{tabular}{lcccccc}
\hline Dimension & Sten & Mean & SD & Skewness & Kurtosis & $\alpha$ \\
\hline Work-Life Balance & 2 & 10,20 & 4,28 & 0,53 & $-0,36$ & 0,68 \\
Resources and Communication & 4 & 12,06 & 4,20 & 0,17 & 0,62 & 0,62 \\
Work Relationships & 5 & 21,74 & 7,24 & 0,64 & 0,15 & 0,78 \\
Overload & 5 & 11,15 & 4,41 & 0,50 & $-0,45$ & 0,76 \\
Job Security & 4 & 11,12 & 3,98 & 0,65 & 0,31 & 0,59 \\
Job Characteristics & 2 & 21,14 & 6,04 & 0,21 & 0,12 & 0,64 \\
Control & 5 & 12,64 & 4,82 & 0,26 & $-0,78$ & 0,81 \\
Pay and Benefits & 6 & 3,55 & 1,75 & $-0,01$ & $-1,44$ & \\
Commitment from & 3 & 18,73 & 5,97 & $-0,30$ & $-0,68$ & 0,84 \\
Organisation & & & & & & \\
Commitment from Individual & 6 & 16,28 & 4,75 & $-0,54$ & $-0,33$ & 0,80 \\
Physical Health & 9 & 15,11 & 4,34 & $-0,21$ & $-0,88$ & 0,80 \\
Psychological Health & 10 & 25,36 & 7,61 & 0,22 & 0,74 & 0,90 \\
\hline
\end{tabular}

Note. The Pay and Benefits scale consists of only one item, and therefore no alpha coefficient is reported for this scale.

Table 1 shows that the 12 dimensions of the ASSET are normally distributed in the sample, with low skewness and kurtosis. The Cronbach alpha coefficients, varying from $0,59-0,90$, compare reasonably well with the guideline of $0,70(0,55$ in basic research), demonstrating that a large portion of the variance is explained by the dimensions (internal consistency of the dimensions) (Nunnally \& Bernstein, 1994).

Physical Health and Psychological Health prove to be major sources of strain, as reflected by the sten scores higher than 8 for these dimensions. The sten of 3 on the dimension Commitment from Organisation indicates that the participants experience the perceived commitment of the organisation as relatively low. The sten of 6 on the dimension of Commitment from the Individual indicates that, in spite of the fact that employees feel that the organisation is failing them, they perceived their own levels of commitment to the organisation as above average (sten of 6).
The sten scores of lower than 3 of Work-Life Balance and Job Characteristics of the ASSET indicate that these two dimensions are perceived as low sources of stress among the population. Three items of the Job Characteristic scale (as measured by the ASSET) also give indications of high levels of stress perceived in these areas, namely "Physical work conditions are unpleasant", "Work performance are closely monitored", and "Organisation is constantly changing for change's sake". Under the dimension of Work Relationships two-stress provoking areas are reflected by these items, namely "Colleagues are not pulling their weight" and "Others take credit for what I have achieved" The low sten on "not adequately trained for job" reflects that the population perceived themselves as qualified to do their respective jobs, and it also seems as if the low score on "Job is not permanent" is indicative of feelings of job security among the population. The other dimensions with sten scores of 4 to 6 indicate average sources of stress.

The product moment correlation coefficients between the ASSET dimensions are given in Table 2 .

Inspection of Table 2 indicates that Physical Health is positively (statistically significantly) related to Work-Life Balance, Resources and Communication, and Control, and practically significantly (medium effect) related to Work Relationships, Job Security and Job Characteristics. Physical Health is negatively related to Overload, Commitment from Individual, and Commitment from Organisation. Psychological Health is positively related (large effect) to Physical Health, and positively related (medium effect) to WorkLife Balance, Resources and Communication, Work relationships, Overload, Job Security, Job Characteristics and Control. Psychological Health is negatively related (statistically significantly) to Commitment from the Individual and Commitment from the Organisation. Commitment from Individual and Commitment from Organisation are negatively related (statistically significantly) to all the dimensions of the ASSET.

The differences for various biographical groups of employees at a higher education institution were analysed in terms of perceived stress as reflected by the results of the ASSET. Because the higher education institution has been actively implementing employment equity (from previously disadvantaged groups who speak African languages), it was decided to compare the ASSET scores of three language groups using ANOVAs followed by Tukey tests (see Table 3 ).

TABLE 2

Product MOMENT CORRELATION COEFFICIENTS OF THE ASSET DIMENSIONS

\begin{tabular}{|c|c|c|c|c|c|c|c|c|c|c|c|}
\hline Dimensions & 1 & 2 & 3 & 4 & 5 & 6 & 7 & 8 & 9 & 10 & 11 \\
\hline 1. Work-Life Balance & - & - & - & - & - & - & - & - & - & - & - \\
\hline 2. Resources and Communication & $0,32^{*+}$ & - & - & - & - & - & - & - & - & - & - \\
\hline 3. Work Relationships & $0,35^{*+}$ & $0,61^{*_{++}}$ & - & - & - & - & - & - & - & - & \\
\hline 4. Overload & $0,56^{\star++}$ & $0,50^{*++}$ & $0,54^{\star_{++}}$ & - & - & - & - & - & - & - & \\
\hline 5. Job Security & $0,19^{\star}$ & $0,45^{\star+}$ & $0,51^{\star++}$ & $0,43^{\star+}$ & - & - & - & - & - & - & \\
\hline 6. Job Characteristics & $0,28^{\star}$ & $0,48^{*_{+}}$ & $0,59^{\star_{++}}$ & $0,47^{\star_{+}}$ & $0,40^{*+}$ & - & - & - & - & - & \\
\hline 7. Control & $0,36^{*+}$ & $0,72^{*++}$ & $0,66^{\star++}$ & $0,46^{*_{+}}$ & $0,50^{\star++}$ & $0,58^{\star++}$ & $0,32^{*+}$ & - & - & & \\
\hline 8. Commitment from Individual & $-0,26^{\star}$ & $-0,50^{\star}$ & $-0,55^{\star}$ & $-0,39^{*}$ & $-0,35^{*}$ & $-0,49^{*}$ & $0,55^{\star}$ & - & - & - & \\
\hline 9. Commitment from Organisation & $-0,16^{*}$ & $-0,40^{*}$ & $-0,36^{*}$ & $-0,36^{*}$ & $-0,20^{*}$ & $-0,38^{\star}$ & $-0,45^{*}$ & $0,78^{*++}$ & - & - & - \\
\hline 10. Physical Health & $0,24^{*}$ & $0,18^{*}$ & $0,35^{*+}$ & $-0,21^{*}$ & $0,33^{*+}$ & $0,35^{*+}$ & $0,15^{*}$ & $-0,27^{*}$ & $0,19^{*}$ & - & - \\
\hline 11. Psychological Health & $0,33^{*_{+}}$ & $0,35^{\star_{+}}$ & $0,46^{\star+}$ & $0,47^{\star_{+}}$ & $0,37^{\star_{+}}$ & $0,45^{\star_{+}}$ & $0,32^{*+}$ & $-0,46^{\star}$ & $-0,40^{\star}$ & $0,70^{\star++}$ & - \\
\hline
\end{tabular}

${ }^{*} p=0,05-$ statistically significant

$+r>0,30$ - practically significant (Medium effect)

$++r>0,50$ - practically significant (Large effect) 
TABLE 3

ANOVAS - DIFFERENCES IN ASSET SCORES OF DIFFERENT LANGUAGE GROUPS

\begin{tabular}{lccccc}
\hline Dimension & Afrikaans & English & Indigenous & $p$ & Root MSE \\
\hline Work-Life Balance & 8,44 & 9,07 & 7,47 & 0,03 & 3,92 \\
Resources and & 10,16 & 9,97 & 9,14 & 0,10 & 3,64 \\
Communication & & & & & \\
Work Relationships & 15,55 & 16,21 & 15,22 & 0,61 & 6,31 \\
Overload & $11,34^{\mathrm{a}}$ & $11,93^{\mathrm{a}}$ & $9,80^{\mathrm{b}}$ & $0,01^{*}$ & 4,37 \\
Job Security & 11,01 & 11,18 & 11,16 & 0,93 & 4,01 \\
Job Characteristics & 14,32 & 13,97 & 12,93 & 0,10 & 5,04 \\
Control & 12,69 & 12,81 & 11,99 & 0,46 & 4,81 \\
Commitment from & 15,82 & $15,24^{\mathrm{a}}$ & $17,85^{\mathrm{b}}$ & $0,00^{*}$ & 4,64 \\
Individual & & & & & \\
Commitment from & $18,19 \mathrm{~b}$ & $17,11^{\mathrm{b}}$ & $21,15^{\mathrm{a}}$ & $0,00^{*}$ & 5,75 \\
Organisation & & & & & \\
Physical Health & 15,27 & 15,61 & 14,56 & 0,29 & 4,33 \\
Psychological Health & $26,66^{\mathrm{b}}$ & 25,70 & $22,42^{\mathrm{a}}$ & $0,00^{*}$ & 7,34 \\
\hline
\end{tabular}

* Statistically significant difference: $p=0,01$

a Practically significant differences from group (in row) where $\mathrm{b}$ (medium effect, $d=0,5$ ) or c (large effect, $d=0,8$ ) are indicated

According to Table 3, both the Afrikaans- and English speaking language groups scored practically significantly higher on Overload (practically significant difference, medium effect) than the indigenous language groups. Indigenous language groups scored significantly higher on Commitment from the Individual in comparison to the Afrikaans-speaking language group (practically significant difference, small effect) as well as the English speaking language group (practically significant difference, medium effect). The indigenous language group also scored significantly higher (practically significant, medium effect) than both the English- and Afrikaans-speaking language groups on Commitment from the Organisation. On Psychological Health, the English-speaking (practically significant difference, small effect) as well as the Afrikaansspeaking language group (practically significant difference, medium effect) scored significantly higher than the indigenous language groups.

The differences in stress levels of groups with different years of experience at the institution are given in Table 4 .

According to Table 4 employees with more than five years experience at the institution scored significantly higher (practically significant difference, medium effect) on Job Characteristics and Control than those with less than five years experience. The employees with fewer than five years experience at the institution scored significantly higher on Commitment from Individual than the two groups with more than five years experience at the institution (practically significant difference, medium effect). They also scored significantly higher on Commitment from Organisation than the two groups with more than five years experience at the institution (practically significant, medium effect). The employees with more than 10 years experience at the institution scored significantly higher on Psychological Health than those with fewer than five years experience at the institution (practically significant, medium effect).

Next, the moderating effect of organisational commitment on health was determined. Firstly, the nine items of the
Organisational Commitment scale of the ASSET were subjected to a principal component analysis. The eigenvalues and scree plot showed that two factors could be extracted. Principal components analysis with a direct oblimin rotation was used to extract the factors. One factor ( 7 items, á $=0,91$ ), which indicated organisational commitment was used. Secondly, the 18 items of the Health subscale of the ASSET was subjected to a principal component analysis. The eigenvalues (larger than one) and scree plot suggested that two factors could be extracted. Principal components analysis with a direct oblimin rotation was used to extract the two factors, namely Physical ill-health (7 items, $\alpha=0,80)$ ) and Psychological ill-health (9 items, $\alpha=0,80$ ). Thirdly, the scales of Perceptions of your Job (of the ASSET) were subjected to a second-order factor analysis. The eigenvalues suggested that all eight scales of the ASSET load on a single factor, Occupational Stress $(\alpha=0,86)$, which explained $56,80 \%$ of the total variance.

TABLE 4

ANOVAS - DIFFERENCES IN ASSET SCORES OF YEARS OF EXPERIENCE CATEGORIES

\begin{tabular}{|c|c|c|c|c|c|}
\hline Dimension & $\begin{array}{l}0-5 \\
\text { years }\end{array}$ & $\begin{array}{c}5,1-10 \\
\text { years }\end{array}$ & $\begin{array}{c}10,1-34 \\
\text { years }\end{array}$ & $p$ & Root MSE \\
\hline Work-Life Balance & 7,58 & 8,13 & 8,88 & 0,10 & 3,89 \\
\hline $\begin{array}{l}\text { Resources and } \\
\text { Communication }\end{array}$ & 8,69 & 10,12 & 9,89 & 0,05 & 3,66 \\
\hline Work Relationships & 14,17 & 15,93 & 15,75 & 0,22 & 6,32 \\
\hline Overload & 10,35 & 10,91 & 11,95 & 0,05 & 4,41 \\
\hline Job Security & 10,58 & 11,01 & 11,42 & 0,43 & 3,98 \\
\hline Job Characteristics & $11,42^{\mathrm{a}}$ & $14,19 \mathrm{~b}$ & $14,18^{b}$ & $0,00^{*}$ & 4,93 \\
\hline Control & $10,29^{a}$ & $12,96^{\mathrm{b}}$ & $12,82^{b}$ & $0,00^{*}$ & 4,73 \\
\hline $\begin{array}{l}\text { Commitment from } \\
\text { Individual }\end{array}$ & $18,21^{\mathrm{a}}$ & $15,71^{b}$ & $15,82^{b}$ & $0,00^{*}$ & 4,67 \\
\hline $\begin{array}{l}\text { Commitment from } \\
\text { Organisation }\end{array}$ & $21,35^{\mathrm{a}}$ & $18,45^{\mathrm{b}}$ & $17,77^{b}$ & $0,00^{*}$ & 5,85 \\
\hline Physical Health & 14,56 & 14,77 & 16,09 & 0,02 & 4,26 \\
\hline Psychological Health & $23,40^{a}$ & 24,99 & $27,23 \mathrm{~b}$ & $0,00^{*}$ & 7,49 \\
\hline
\end{tabular}

* Statistically significant difference: $p=0,01$

a Practically significant differences from category (in row) where $\mathrm{b}$ (medium effect, $d=$

0,5 ) or c (large effect, $d=0,8$ ) are indicated

Structural equation modelling was used to test whether occupational stress leads to ill-health and to determine whether organisational commitment moderates the effects of occupational stress on health. The final model is given in Figure 2 .

Results indicated that the model did fit the data adequately $\left(\chi^{2}\right.$ $=109,19, \mathrm{GFI}=0,95, \mathrm{AGFI}=0,91, \mathrm{NFI}=0,94, \mathrm{IFI}=0,96, \mathrm{TLI}=$ $0,94, \mathrm{CFI}=0,96$ and RMSEA $=0,08$ ). As can be seen in Figure 2, the path from Occupational Stress to Ill-health is significant. This means that high levels of occupational stress as experienced by employees may result in ill-health with either physical or psychological health problems, or both. According to the model, it seems that individual commitment to the organisation moderates the effect of occupational stress on illhealth. It means that the level of ill-health depends not only on the level of occupational stress, but also on the level of individual commitment to the organisation. It is indicated in Figure 1 that $48 \%$ of the variance in organisational commitment is explained by occupational stress and $28 \%$ of the variance in ill-health is explained by organisational commitment and occupational stress. 


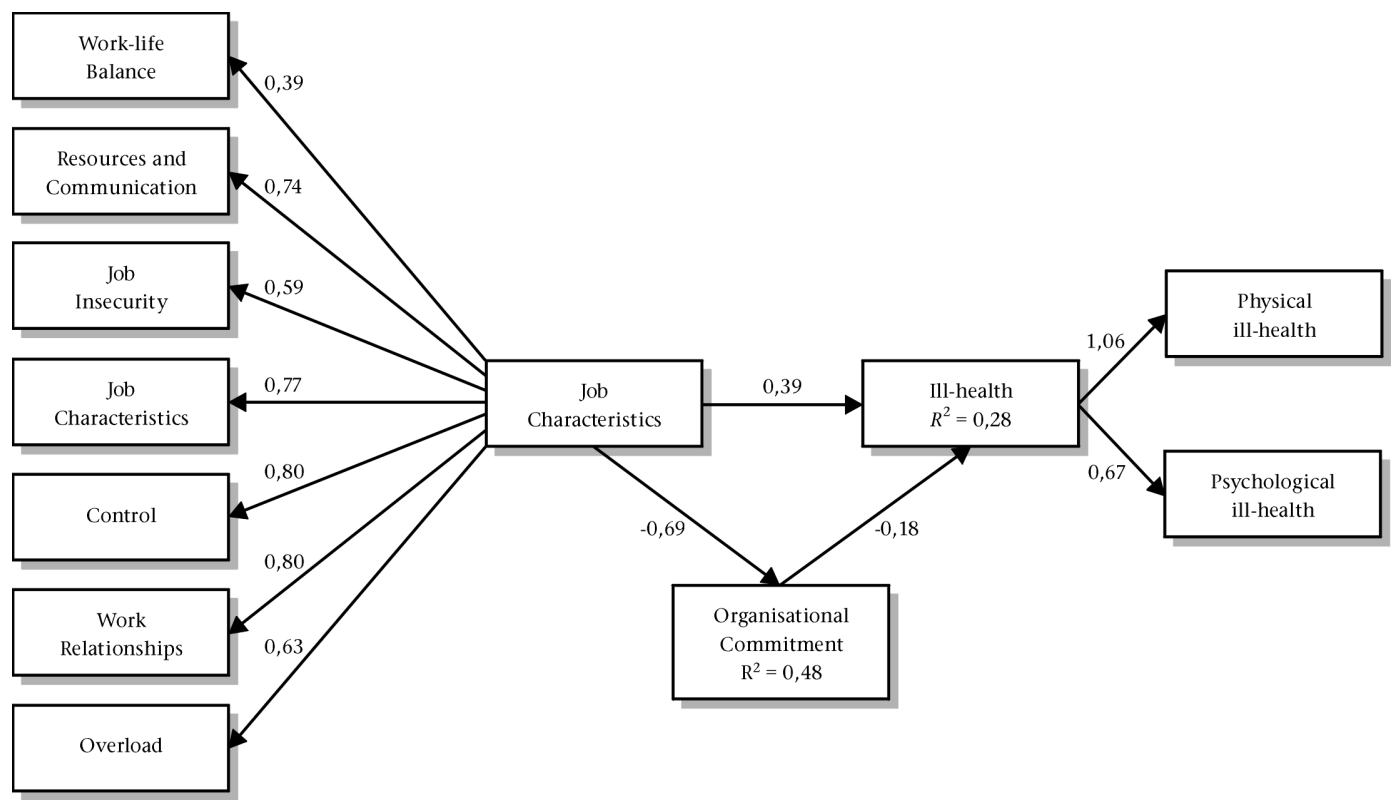

Figure 2: Commitment from the individual as a moderator of the effect of occupational stress on (ill) health (standardised solution). (Note: All factor loadings and path coefficients are significant, $p<0,01$ ).

\section{DISCUSSION}

The objectives of this study were to identify the occupational stressors for staff members in a higher education institution; to assess the relationship between occupational stress, organisational commitment and ill-health, and analyse the differences between groups based on language and years of experience. Reliability analysis revealed that all the dimensions were sufficiently internally consistent.

This was the first study in South Africa to use the ASSET as a stress assessing tool, and to compare the findings to established normative data in order to determine a stress profile of employees within a specific higher education institution. The results reveal that the sources of strain which the respondents were most troubled by were the lack of commitment that they perceived from the organisation. High levels of physical and psychological outcomes of stress were also found.

An interesting finding was that employees felt that the institution is not committed to them. This is significant in the light of the fact that employees perceived themselves as relatively highly committed to the organisation. The only direct comparison that can be made is to the study of Tytherleigh et al. (2003), who used the same measuring instrument in their study of 14 United Kingdom universities and colleges. Levels of commitment, both perceived from and felt toward their organisations, were also an area of concern for higher education staff. Commitment levels, and the potential effect that they may have specifically on the institution researched in this study, can result in reduced levels of productivity and unwillingness to assume responsibility (Chow, 1990).

Physical and psychological outcomes of stress were high compared to the normative sample. This is in line with the findings of Winefield et al. (2002) that 50\% of Australian university staff in their study were at risk of psychological illness, compared to only $19 \%$ of the Australian population. Several physical (e.g. headaches, nausea, muscular tension/pains, and insomnia) and psychological symptoms (panic attacks, constant irritability/anger, mood swings, tiredness, inability to cope and avoidance of other people) were perceived, to such an extent that it could have a detrimental effect on work performance. This finding differs from the results of Tytherleigh et al. (2003), who found lower levels of physical outcomes of stress and normative levels of psychological well-being for their population.

Compared to normative data the employees of this institution were more stressed by aspects of work relationships (in particular some people not pulling their weight, and others taking credit for what is not their own their achievements). They were also stressed by job characteristics (constant changes within the organisation, physical working conditions, and the way work performance is measured). These indicators could, if not attended to, in the longer run result in corrosion of organisational commitment.

The results indicate that occupational stress within this institution is a problem and lend further support to the growing evidence that higher education institutions no longer provide the low-stress working environments they once did (Tytherleigh et al. 2003; Winefield et al. 2002). Furthermore, they support the findings of a national survey of Britain's professional workforce carried out in 1996, which found that university lecturers and researchers reported lower levels of perceived commitment from their organisation, compared to 20 other occupational groups (Millward-Brown, 1996). Organisational commitment is an established indicator of motivation (Brown, 1996; Mayer \& Schoorman, 1992) and a moderator of stress (Siu, 2002), particularly during periods of organisational change. Keeping in mind that most of the respondents feel that they 'cannot be proud of the organisation' and that the organisation is only 'changing for the sake of change' these findings suggest that the issue of perceived commitment is a serious concern that needs to be addressed.

Evaluation of the Pearson correlations of the ASSET dimensions showed that physical health is negatively related to overload, commitment from the organisation, and commitment from the individual. Psychological health was also negatively related to commitment from the organisation and commitment from the individual.

An analysis of the impact of the biographical characteristics of the population on perceived stress levels reveals that higher levels of commitment from the individual were reflected by the indigenous language speaking group ( $26 \%$ of the population) in comparison to the English (19\% of the population) and Afrikaans 
(55\% of the population) language groups. The Indigenous language speaking groups also perceived significantly higher commitment from the organisation in comparison to the other two groups. Both the English-speaking and the Afrikaansspeaking groups gave indications of significantly higher perceived psychological stress in comparison to the indigenous speaking language groups. These two groups also experienced significantly higher levels of overload.

These observations might be understood if radical transformation of the higher education institution during the past eight years is taken into account. The Afrikaans- and English-speaking groups are mainly white staff who have been at the institution for more than five years. They had to adapt to changes like a new transformed management team, new organisational climate and culture, a transformed student population, as well as a different official language at the institution over a relatively short period of time. Difficulty in adapting to and integrating the impact of these changes might be reflected in the lower levels of commitment and higher levels of overload and psychological stressors perceived by these groups in comparison to the black indigenous language speaking groups.

These observations are further confirmed by the fact that employees with more than five years of experience at the institution (68\% of the population) are perceiving characteristics of their jobs and control as a big source of stress, are perceiving the organisation as less committed to them, and are showing signs of being less committed to the organisation in comparison to those with fewer than five years of experience at the institution. Employees with more than 10 years experience at the institution also show significantly higher indications of psychological ill-health.

Limitations of the present study include the sample size $(N=372)$ and the sampling procedure. Both these aspects have an impact on the possibility of generalisation of the findings to the total study population. Future studies could benefit in terms of a stratified random-sample design which would ensure sufficient representation of the different groups in the total population. Future studies should also focus on longitudinal designs where inferences in terms of cause and effect could be drawn. A further limitation of this study is its reliance solely on self-reporting measures. Future studies should also consider extending the sample to include employees of all the higher education institutions in South Africa in order to standardise the ASSET for employees of higher education institutions in South Africa.

\section{RECOMMENDATIONS}

The higher education institution should intervene to reduce the occupational stress of staff members. According to Kompier and Kristensen (2001), primary interventions may, in the first place, be directed at either the work situation or the coping capacity of the employee. If the physical and psychological stressors especially are allowed to continue unattended, the organisation can expect to find negative costs associated with continued elevated levels of stress, such as burnout, absenteeism, employee turnover and lowered levels of service. Interventions may be aimed at eliminating, reducing or altering stressors. Possible interventions include: Provision of a more supportive climate; changes in decision-making processes; tangible evidence of commitment from the organisation; and establishment of a more equitable system of reward and resource distribution. Secondary level interventions can be implemented to prevent employees and specific groups who are already showing signs of stress from getting sick and to increase their coping capacity.

In terms of the experience of strain by the population, the low perceived level of commitment from the organisation is a concern. With regard to the motivation of employees and the building of credibility by and co-operation in the organisation, interventions aimed at maximising group effectiveness, increasing a sense of belonging and shared vision; rebuilding trust relationships; and an organisational commitment to fairness and equity should be considered. A leadership skills intervention aimed at first-line management could be considered in this regard.

Finally, it is recommended that with regard to the perceived occupational stress of South African employees of higher education institutions specifically and organisations in general, the current findings based on the results of the ASSET be validated with regard to the equal comparison of the perceived strain construct across cultural groups in order to be able to generalise findings in the multi-cultural South African context.

\section{Author's Note}

The material described in this article is based upon work supported by the National Research Foundation (Grant number 2053344)

\section{REFERENCES}

Altbach, P.G. (1996). The international academic profession. Princeton, NJ: Carnegie Foundation for the Advancement of Teaching.

Arbuckle, J.L. (1997). Amos user's guide version 3.6. Chicago: Smallwaters.

Bentler, P.M. (1990). Comparative fit indexes in structural models. Psychological Bulletin, 107, 238-246.

Bentler, P.M. (1992). On the fit of models to covariances and methodology to the Bulletin. Psychological Bulletin, 112, $400-404$.

Blackmore, J. (2001). Universities in crisis? Knowledge economics, emancipatory pedagogies, and the critical intellectual. Educational Theory, 51, 353-370.

Boyd, S. \& Wylie, C. (1994). Workload and stress in New Zealand universities. Wellington: New Zealand Council for Educational Research and the Association of University Staff of New Zealand.

Brown, P. (1999). Globalization and the political economy of high skills. Journal of Education and Work, 12, 233-251.

Brown, S.P. (1996). A meta-analysis and review of organisational research on job involvement. Psychological Bulletin, 120, 235-255.

Byrne, B.M. (2001). Structural equation modeling with AMOS: Basic concepts, applications and programming. Mahwah, NJ: Erlbaum.

Cartwright, S. \& Cooper, C.L. (2002). ASSET: An Organizational Stress Screening Tool - The Management Guide. Manchester, RCL Ltd.

Chow, I.H.S. (1990). An empirical assessment of organisational commitment among local employees. Human Resources Journal, 6 (1), 32-38.

Clark, L.A. \& Watson, D. (1995). Constructing validity: Basic issues in objective scale development. Psychological Assessment, 7, 309-319.

Cohen, J. (1988). Statistical power analysis for the behavioral sciences. ( $2^{\text {nd }}$ ed.). Hillside, NJ: Erlbaum.

Cooper, C.L., Dewe, P.J. \& O'Driscoll, M.P. (2001). Organisational stress: A review and critique of theory, research, and applications. Thousand Oaks, CA: Sage.

Cross, M., Mungadi, R. \& Rouhani, S. (2002). From policy to practice: Curriculum reform in South African education. Comparative Education, 38, 171-187.

Daniels, K. \& Guppy, A. (1994). An exploratory study of stress in a British university. Higher Education Quarterly, 48, 135-144.

Dlamini, C.R.M. (1995). The transformation of South African universities. South African Journal of Higher Education, 9 (1), $39-46$. 
Doyle, C. \& Hind, P. (1998). Occupational stress, burnout and job status in female academics. Gender, Work and Organisation, 5, 67-82.

$\mathrm{Du}$ Toit, A. (2000). Critic and citizen: The intellectual transformation and academic freedom. Pretexts: Literary and Cultural Studies, 9 (1), 91-104.

Earley, P. (1994). Lecturers' workload and factors affecting stress levels. Slough: NFER.

French, J.R.P., Caplan, R.D. \& Van Harrison, R. (1982). The mechanisms of job stress and strain. Buckingham: Open University Press.

Gilbert, A.D. (2000). The idea of a university beyond 2000 . Policy, 16, 31-36.

Gillespie, N.A., Walsch, M., Winefield, A.H., Dua, J. \& Stough, C. (2001). Occupational stress in universities: Staff perceptions of the causes, consequences and moderators of stress. Work and Stress, 15, 53-72.

Goldberg, D.P. \& Williams, P. (1988). A user's guide to the GHQ. London: NFER, Nelson.

Gorshkov, A. (1998). Regional scientific and educational complexes in the Russian federation: Essence, forms and mechanisms of formation. Higher Education in Europe, XXIII, $407-412$.

Houkes, I., Janssen, P.P.M., de Jonge, J. \& Nijhuis, F.J.N. (2001). Specific relationships between work characteristics and intrinsic work motivation, burnout and turnover intention: A multi-sample analysis. European Journal of Work and Organizational Psychology, 10, 1-23.

Hu, L.T. \& Bentler, P.M. (1999). Cutoff criteria for fit indexes in covariance structure analysis: Conventional criteria versus new alternatives. Structural Equation Modeling: A Multidisciplinary Journal, 6, 1-55.

Hugo, P. (1998). Transformation: The changing context of academia in post-apartheid South Africa. African Affairs, 97, 5-27.

Jackson, C. \& Hayday, S. (1997). Staff attitudes at the University of Central Lancashire. Brighton: Institute for Employment Studies.

Johnson, S. \& Cooper, C. (2003). The construct validity of the ASSET stress measure. Manuscript made available by authors.

Jones, J.R. \& Hodgson, J.T. (1998). Self-reported work-related illness in 1995: Results from a household survey. London: HSE Books.

Jöreskog, K.G. \& Sörbom, D. (1993). Testing structural equation models. In K.A. Bollen \& J.S. Long (Eds.), Testing structural equation models (pp. 294-316). Newbury Park, CA: Sage.

Kinman, G. (1996). Occupational stress and health among lecturer's working in further and higher education. London: National Association of Teachers in Further and Higher Education.

Kinman, G. (2001). Pressure points: A review of stressors and strains in UK academics. Educational Psychology, 21, 474-492.

Kinman, G. \& Jones, F. (2003). 'Running up the down escalator': Stressors and strains in UK academics. Quality in Higher Education, 9 (1), 22-38.

Kompier, A.J. \& Kristensen, T.S. (2001). Organisational work stress interventions in a theoretical, methodological and practical context. In J. Dunham (Ed.), Stress in the workplace: Past, presence and future (pp.19-33). London: Whurr Publishers.

Lazarus, R.S. (1991). Psychological stress in the workplace. Journal of Social Behaviour and Personality, 6, 1-13.

Mayer, R.C. \& Schoorman, D.F. (1992). Predicting participant and production outcomes through a two-dimensional model of organisational commitment. Academy of Management Journal, 35, 671-684.
Millward-Brown. (1996). Powerful people: A survey of Britain's professional workforce. Guardian Publishing Group.

Nunnally, J.C. \& Bernstein, I.H. (1994). Psychometric theory (3 $3^{\text {rd }}$ ed.). New York: McGraw-Hill.

Rowley, R. (2000). Is higher education ready for knowledge management? The International Journal of Educational Management, 14, 325-333.

Schaufeli, W.B. \& Enzmann, D. (1998). The burnout companion to study and practice: A critical analysis. London: Taylor \& Francis.

Schaufeli, W.B. Enzmann, D. \& Girault, N. (1993). Measurement of burnout: A review. In W.B. Schaufeli, C. Maslach \& T. Marek (Eds.), Professional burnout: Recent developments in theory and research (pp. 199-215). Washington: Taylor \& Francis.

Seldin, P. (1991). Reducing stress on campus. Planning for Higher Education, 9 (4), 14-20.

Shaughnessy, J.J. \& Zechmeister, E.B. (1997). Research methods in psychology (4th ed.). New York: McGraw-Hill.

Shortlidge, R.L. Jr. (2003). University training for Gramsevaks in India: An example of recurrent education in a lowincome country. Center for Human Research Ohio State University.

Siu, O.L. (2002). Occupational stressors and well-being among Chinese employees: The role of organizational commitment. Applied Psychology: An International Review, 5, $527-544$.

Steyn, H.S. (1999). Praktiese betekenisvolheid: Die gebruik van effekgroottes. Wetenskaplike bydraes, Reeks B: Natuurwetenskappe Nr. 117. [Practical significance: Use of effect sizes]. (Scientific contributions, Series B, Natural Sciences, No. 117). Potchefstroom, South Africa: Potchefstroom University for Christian Higher Education, Statistical Consultation Services.

Tytherleigh, M.Y. (2002). Occupational stress in higher education institutions: Phase I. UK: University of Plymouth Institute of Health Studies.

Tytherleigh, M.Y. (2003). What employers may learn form English higher education institutions: A fortigenic approach to occupational stress. South African Journal of Industrial Psychology, 29 (4), 101-106.

Tytherleigh, M.Y., Webb, C., Cooper, C.L. \& Ricketts, C. (2003). Occupational stress in UK higher education institutions: A comparative study of all staff categories. Manuscript submitted for publication.

Watts, W.D., Cox, L., Wright, L.S., Garrison, J., Herkimer, A. \& Howze, H.H. (1991). Correlates of drinking and drug use by higher education faculty and staff: Implications for prevention. Journal of Drug Education, 21, 43-64.

Willie, R. \& Stecklein, J.R. (1982). A three-decade comparison of college faculty characteristics, satisfactions, activities and attitudes. Research in Higher Education, 16, 81-93.

Winefield, A.H., Gillispie, N., Stough, C., Dua, J. \& Hapuararchchi, J. (2002). Occupational stress in universities: A national survey. Melbourne: National Tertiary Education Union.

Winefield, A., Gillespie, N., Stough, C., Dua, J., Hapuararchchi, J. \& Boyd, C. (in press). Occupational stress in Australian university staff: Results from a national survey. International Journal of Stress Management.

Wright, L.A. \& Smye, M.D. (1996). Corporate abuse: How lean and mean robs people and profits. New York: Macmillan. 